\title{
Local immunity in ulcerative colitis: evidence for defective secretory IgA production
}

\author{
S BADR-EL-DIN, L K TREJDOSIEWICZ, R V HEATLEY, \\ AND M S LOSOWSKY \\ From the Department of Medicine, University of Leeds, St James's Hospital, Leeds
}

SUMMARY To investigate local humoral immunity in ulcerative colitis (UC), immunoglobulin (Ig) contents and net Ig production in vitro was assessed using organ cultures of colonic biopsies from 21 patients with quiescent disease and 11 controls. Ig was estimated by enzyme linked immunoassay (ELISA) for IgA, secretory IgA (sIgA), IgM, and IgG. In parallel, numbers of IgA plasma cells were estimated by indirect immunoperoxidase staining of tissue sections for IgA. IgA was the dominant Ig isotype found pre-existing in colonic mucosae, and secreted in vitro. In UC patients, preformed tissue IgA and IgA produced in vitro were significantly increased compared with controls. There was no concomitant increase in amounts of sIgA synthesised in culture, however, although numbers of IgA plasma cells were increased in UC patients by an amount comparable with the increased in vitro IgA production. These results directly show a dysfunction of transepithelial IgA secretion in quiescent ulcerative colitis. Despite a significantly raised concentration of tissue IgG in UC patients, little was produced in vitro in patient and control groups alike, suggesting that mucosal IgG was serum derived, and not linked to local IgA production.

Studies of systemic humoral immunity in patients with ulcerative colitis (UC) have not shown major perturbations. At the level of the colonic mucosa, however, there are clearer indications that a humoral immune response is involved in UC, seen mainly as an increase in the numbers of plasma cells, particularly of the IgA isotype. ${ }^{12}$ There is also evidence of increased local Ig production in patients with UC, as shown by in vitro culture of biopsies ${ }^{3+}$ and isolated intestinal cells. ${ }^{5}$ Nevertheless, in vitro production of the $\operatorname{IgA}$ isotype by isolated intestinal mononuclear cells is decreased rather than raised in UC, when calculated on a 'per cell' basis. ${ }^{6-8}$

Immunohistological studies have shown a marked decrease, or even absence of $\operatorname{IgA}$ from colonic epithelium in UC, despite the presence of secretory component $^{2-11}$ and the normal production of secretory component in vitro. ${ }^{32}$ These data are suggestive of a defect in production of secretory component-bound secretory $\operatorname{Ig} \mathrm{A}(\mathrm{s} \operatorname{IgA})$ in patients

Address for correspondence: R V Heatley, MD, Department of Medicine, St James's University Hospital, Leeds LS9 7TF.

Received for publication 12 February 1988. with UC, possibly as a result of decreased J-chain production by mucosal plasma cells, ${ }^{11}$ or because of an increased proportion of the $\operatorname{IgA}$ being produced in monomeric form as part of the normal local immune response. ${ }^{x}$ No direct evidence for this hypothesis has been forthcoming, however. Clearly, the production of non-secretory and secretory forms of IgA in the colonic mucosa of patients with UC needs further investigation. To these ends, we have studied in vitro synthesis of immunoglobulins, with special emphasis on IgA and secretory IgA as a correlate of plasma cell density.

\section{Methods}

PATIENTS AND TISSUE SAMPLES

Twenty one patients with UC (10 men, age range 24-66 years, mean $=42$ ), in whom the diagnosis had been substantiated by conventional means of endoscopy, biopsy histology and often radiology, were studied at follow up clinics. The duration since first diagnosis ranged from three to 40 years $($ mean $=9$ ), although none of the patients had active disease at the time of study. Nine patients were on cortico- 
steroid treatment during the month preceding the study, 12 were on sulphazaline, four were receiving both treatments and four were not on any specific therapy. The control group included 11 patients (five men; age range $26-49$ years, mean $=39$ ) with noninflammatory conditions (five with diverticular disease, four with irritable bowel syndrome, one with benign adenomatous polyps, and one with angiodysplasia of the caecum); none were receiving any specific therapy at the time of study. Multiple biopsies were obtained from adjacent sites of the descending colon from each patient during routine colonoscopy. Two biopsies were placed immediately into tissue culture medium and cultured within five minutes of collection, two were weighed and homogenised for estimation of tissue Ig contents, and a fifth biopsy (when available) was fixed in neutral buffered formalin for histological sectioning and subsequent plasma cell enumeration.

\section{ORGAN CULTURE}

A grid organ culture method was used ${ }^{13}$ as previously described in detail. ${ }^{1+15}$ Briefly, biopsies were orientated luminal side uppermost and placed on stainless steel grids in organ culture chambers (Falcon) filled with $1.3 \mathrm{ml}$ RPMI 1640 culture medium, supplemented with $10 \%$ fetal bovine serum and penicillin/ streptomycin (Flow Laboratories), just sufficient to ensure that a thin layer of liquid was drawn over the mucosal surface by capillary action. Duplicate cultures were maintained at $37^{\circ} \mathrm{C}$ in a humidified atmosphere of $5 \% \mathrm{CO}_{2}, 95 \% \mathrm{O}_{2}$. After three days culture, the supernatants were carefully collected, and the biopsies were weighed, homogenised in $2 \mathrm{ml}$ saline, and clarified by centrifugation. Samples were stored aliquoted at $-20^{\circ} \mathrm{C}$ before assay for Ig contents.

\section{ESTIMATION OF IMMUNOGLOBULINS}

A sensitive enzyme linked immunoassay (ELISA) technique was used to estimate Ig content of biopsies and culture supernatants for total IgG, IgM, nonsecretory $\operatorname{Ig} \mathrm{A}$, and secretory $\operatorname{Ig} \mathrm{A}(\mathrm{sIg} \mathrm{A})$, as described previously. ${ }^{16}$ For estimation of total immunoglobulins, a polyvalent antihuman Ig purified antibody was used as the solid-phase 'capture' reagent, whereas for estimation of $\operatorname{sIgA}$, a specific antisecretory component purified antibody (Seward Laboratories) was used. Alkaline phosphataseconjugated isotype-specific antihuman $\operatorname{IgG}, \operatorname{IgM}$, and IgA affinity purified second layers were used for the quantitation of each isotype. All antibodies and conjugates were obtained from Sigma, except where noted. Immunoglobulin standards were derived from pooled sera (Seward), colostral IgA (Sigma) was used as the sIgA standard. ${ }^{16}$ To obtain values of nonsecretory $\operatorname{Ig} \mathrm{A}$, the $\operatorname{sIg} \mathrm{A}$ concentration was sub- tracted from the total IgA value. In this assay, fetal bovine serum in culture media does not interfere. ${ }^{15}$ The concentration of preformed material in duplicate uncultured biopsies was calculated, and subtracted from the gross Ig production in culture (derived from the total amount found in culture supernatant plus the contents of the biopsy after culture) to arrive at a figure for net synthesis in vitro, expressed as 'ng Ig/mg weight of biopsy'.

\section{IgA PlaSma CELL ENUMERATION}

An indirect immunoperoxidase technique was used to label trypsinised $5 \mu \mathrm{m}$ paraffin sections, as previously described. ${ }^{\text {is }}$ Briefly, after quenching of endogenous peroxidase and pre-incubation with normal swine serum, unconjugated antibodies to $\operatorname{IgA}$ (Dakopatts), $\operatorname{Ig} A_{1}$ and $\operatorname{IgA} A_{2}$ (Nordic) were incubated on serial sections. The reaction was detected with swine antirabbit peroxidase conjugated second antibody (Dakopatts), and visualised with diaminobenzidine. Controls included omission of primary and/or second layer antibodies, and absorption of primary antibodies with purified $\operatorname{IgA}$ and/or lyophilised normal human serum. ${ }^{15}$ Microscope slides were projected onto a large sheet of graph paper using a Leitz projecting microscope at a standard distance. The number of peroxidase labelled cells identifiable morphologically as plasma cells were counted per unit area of the lamina propria to obtain a figure on a 'per $\mathrm{mm}^{2}$ ' basis. A stage micrometer slide (Graticules Ltd) was used to obtain the exact magnification factor. At least 200 cells were counted per specimen.

\section{STATISTICAL ANALYSIS}

The two-tailed Mann-Whitney U-test was used to evaluate comparative statistical significance; means and standard deviations were used as descriptive statistics.

\section{Results}

IMMUNOGLOBULIN CONTENTS OF COLONIC BIOPSIES

$\operatorname{IgA}$ was the predominant Ig isotype found preexisting in the tissues (Fig. 1). In control patients, the isotype ratios $\operatorname{IgA}: \operatorname{IgA}: \operatorname{IgM}: \operatorname{IgG}$ were $4: 1: 1: 1: 5$ respectively, whereas in the UC patients, the isotype ratios were $6: 1: 1: 1: 5$ respectively, reflecting an overall increase in IgA tissue content (Fig. 1). The amount of Ig present overall in the colonic mucosa of patients with UC was higher than that found in the controls; the amount of IgA was more than doubled $(p<0 \cdot 01)$ and IgG levels were significantly raised $(p<0 \cdot 01)$, although to a lesser extent. Although tissue levels of $\operatorname{sgA}$ and IgM were also slightly 

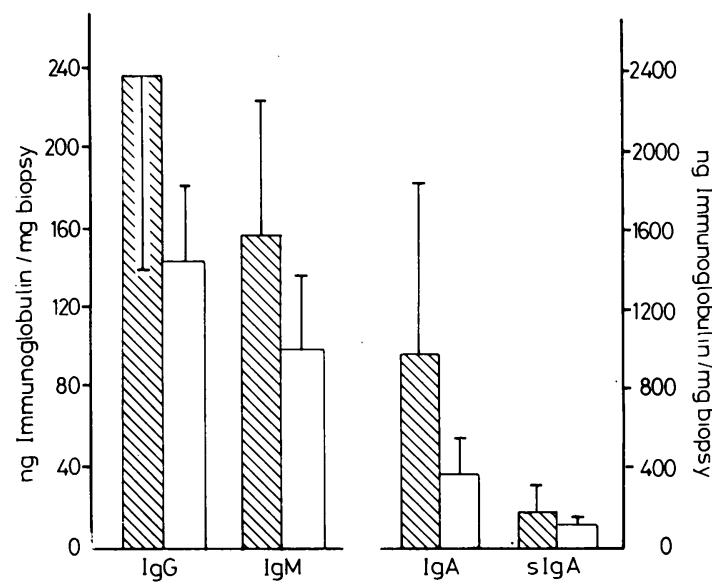

Fig. 1 Immunoglobulin contents of colonic mucosal biopsies estimated by ELISA for IgG, IgM, IgA and secretory $\operatorname{Ig} A(\operatorname{sg} A)$. Means and standard deviations plotted. Shaded bars-ulcerative colitis patients; open barscontrol patients. NB 10-fold scaling factor for IgA and sIgA.

increased in UC, the results were not statistically significant.

\section{IMMUNOGLOBULIN PRODUCTION IN VITRO}

In biopsies from control patients, increased production of $\operatorname{IgA}$ and $\operatorname{IgM}$ (Fig. 2) altered the isotype ratio to $20: 6: 2: 1$ for IgA:sIgA:IgM:IgG, respectively. Net $\mathrm{IgG}$ production was very low, and in four cases was effectively zero. In cultured biopsies from UC patients, IgA production predominated, and resulted in similar isotype ratios compared with controls (20:2:1:1), although the absolute net amount of IgA produced was more than double $(\mathrm{p}<0.05)$. There was no commensurate rise of $\operatorname{sIgA}$ production in vitro, however, the amounts produced being no higher than those of control biopsies (Fig. 2). Thus, whereas in the control group, sIgA accounted for nearly one third of all IgA produced, in the patients with UC, net $\operatorname{SIgA}$ production was only about one tenth of total IgA secretion. In UC patients, production of IgM was higher than in controls, although the difference was not statistically significant. Net IgG production was negligible in three individuals with UC, whereas several other patients showed quite high production. Because of large individual scatter, however, the difference between control and UC patients was not statistically significant.

IgA PLASMA CELLS

Tissue sections from nine UC patients and six controls were available for the study (Table). There was a considerable increase in absolute numbers (per $\mathrm{mm}^{2}$ of lamina propria) of IgA plasma cells in the
Table IgA containing plasma cells and IgA subtypes in the colonic mucosa

\begin{tabular}{llll}
\hline & $\begin{array}{l}\text { Absolute no } \\
\text { of IgA cells }\end{array}$ & $\begin{array}{l}\text { IgA, cells } \\
(\%)\end{array}$ & $\begin{array}{l}I g A_{2} \text { cells } \\
(\%)\end{array}$ \\
\hline Ulcerative colitis & 788 & 68 & 32 \\
& 810 & 57 & 43 \\
& 625 & 60 & 40 \\
& 588 & 62 & 38 \\
& 627 & 63 & 37 \\
& 808 & 63 & 37 \\
Mean & 420 & 64 & 36 \\
SD & 1167 & 71 & 29 \\
Controls & 729 & 58 & 42 \\
& $729 \cdot 11$ & $62 \cdot 89$ & $37 \cdot 11$ \\
& $207 \cdot 58$ & $4 \cdot 48$ & $4 \cdot 48$ \\
& 337 & 45 & 55 \\
& 220 & 57 & 43 \\
Mean & 369 & 69 & 31 \\
SD & 223 & 52 & 48 \\
Significance & 453 & 56 & 44 \\
& 320 & 56 & 44 \\
& $320 \cdot 33$ & $55 \cdot 83$ & $44 \cdot 17$ \\
& $89 \cdot 20$ & $7 \cdot 83$ & $7 \cdot 83$ \\
& $\mathrm{p}<0 \cdot 01$ & $\mathrm{NS}$ & $\mathrm{NS}$ \\
\hline
\end{tabular}

*Absolute numbers expressed as cells $/ \mathrm{mm}^{2}$ lamina propria:

$\mathrm{SD}=$ standard deviation; $\mathrm{NS}=$ not statistically significant .

colonic mucosa of patients with UC, compared with controls $(p<0 \cdot 01)$. The magnitude of increase (over two-fold) was comparable with the increased $\operatorname{IgA}$ contents and IgA secretion rates noted above. There was no correlation, however, between IgA plasma cells and either tissue content or production of $\operatorname{sIgA}$.

The increase in numbers of IgA plasma cells was observed for both $\operatorname{IgA}$ subtypes: the ratio of $\operatorname{IgA} \mathrm{A}_{1}$ to $\operatorname{Ig} A_{2}$ plasma cells in UC patients $(62.9 \%$ to $37 \cdot 1 \%$,

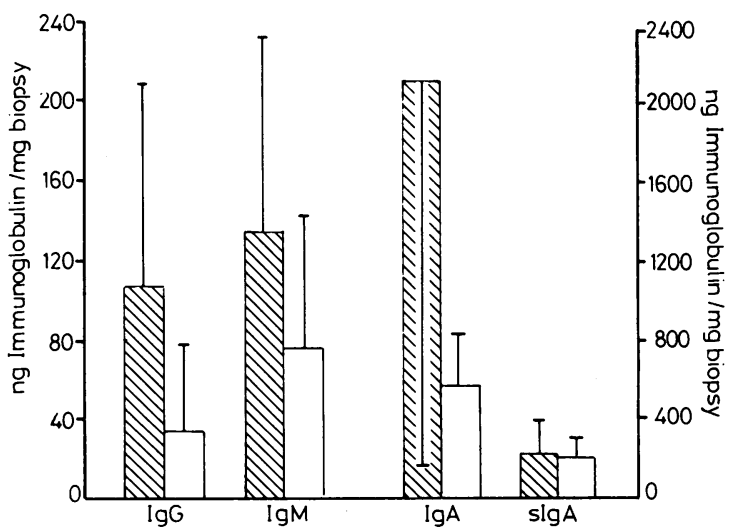

Fig. 2 Net immunoglobulin secretion by colonic mucosal biopsies in vitro (means and standard deviations). Shaded bars-ulcerative colitis patients; open bars-control patients. NB 10-fold scaling factor for IgA and IgA. Although overall IgA secretion is considerably increased in ulcerative colitis patients, there is no concomitant increase of $\operatorname{sIg} A$. 
respectively), although slightly increased, was not significantly altered from the proportions observed in control patients $(55.8 \%$ to $44.2 \%$, respectively) (Table).

\section{Discussion}

IgA-secreting cells are the dominant plasma cell type in the colonic mucosa, and our data indicate that an important feature of local mucosal immunity associated with ulcerative colitis involves the $\mathrm{IgA}$ response. Previous studies of colonic mucosal plasma cells have reported increases in numbers in UC, ${ }^{12}{ }^{17-211}$ although individual reports show some discrepancies. In recent reviews, ${ }^{\prime 2}$ such discrepancies were attributed to methodological problems and the fact that selection of tissue samples poses considerable problems due to histopathological variability within specimens, especially in cases of active inflammatory bowel disease. We chose to study patients with quiescent disease as the variability is less marked in the mucosa of such patients, and our data are in good overall agreement with most previous reports.

Alterations in $\operatorname{IgA}$ subtype have not been studied extensively in UC. It has been reported that there is a preferential increase in $\operatorname{Ig} \mathrm{A}_{1}$ subtype secretion by isolated colonic cells in $\mathrm{UC},{ }^{8}$ and very recently, a substantial increase in numbers of $\operatorname{Ig} \mathrm{A}_{1}$ cells has been reported. ${ }^{21}$ Our data suggested that the increase in $\operatorname{Ig} \mathrm{A}_{1}$ plasma cells was modest, but not statistically significant. As all our patients were in remission, these observations suggest that a marked increase in $\operatorname{Ig} \mathrm{A}_{1}$ occurs only in patients with active disease.

Several groups have studied Ig production in the colonic mucosa of UC patients. The increased production reported previously using organ cultures ${ }^{3+}$ was not specifically compared with numbers of plasma cells, nor to the pre-existing tissue contents. Careful studies using cultures of isolated cells indicated a reduction, however, rather than a rise in IgA secretion on a 'per cell' basis. ${ }^{78}$ Our data demonstrate that the increase of $\operatorname{IgA}$ production by organ cultures is a function of numbers of plasma cells, and does not reflect any increase in rate of synthesis on a 'per cell' basis. These observations therefore agree with functional studies of isolated cell populations ${ }^{8}$ and with immunohistological investigations. ${ }^{21}$

Whereas the production of $\operatorname{IgA}$ in the colonic mucosa of patients with UC was substantially raised, there was no concomitant increase of secretory $\operatorname{IgA}$ production, either preformed in the tissues, or secreted during organ culture. Thus a 'leakage' effect of de novo synthesised $\operatorname{IgA}$ through the stroma during culture is unlikely to wholly account for our data, and would equally apply to the control tissues.
Although secretory $\operatorname{IgA}$ production has not been previously directly estimated in the colonic mucosa, several reports have suggested that secretory $\operatorname{IgA}$ production may be deficient in patients with UC. Immunohistological studies have shown that amounts of $\operatorname{IgA}$ found within colonic epithelial cells are low, ${ }^{411}$ implying that despite the raised numbers of plasma cells and increased overall rate of production, there is a defect of secretory component binding and transepithelial transport.

Damage to enterocytes in UC may impair synthesis of secretory component, or perturb IgA binding to secretory component expressed on the basolateral surface of enterocytes, its subsequent internalisation and resecretion into the gut lumen. Immunohistological studies, however, suggest that amounts of epithelial secretory component are not markedly perturbed $^{211}$ and normal production of secretory component was reported in vitro, ${ }^{312}$ suggesting that the defect lies elsewhere. Indeed, functional assays have shown that less dimeric $\operatorname{IgA}$ is secreted by isolated mucosal cells in $\mathrm{UC}^{\times}{ }^{\times}$and immunohistological evidence has been presented for a defect in dimeric IgA production by the plasma cells, manifest as reduced expression of the J-chain component," thereby reducing the ability of $\operatorname{IgA}$ to bind secretory component.

Defective secretory $\operatorname{IgA}$ production may play a crucial role in the pathogenesis of UC. Impaired defences against influx of potentially antigenic material would increase local immunostimulation, resulting in raised local production of $\operatorname{IgA}$, which, however, would remain ineffective. A second consequence would be a local inflammatory reaction, leading to increased tissue permeability, thereby promoting ingress of gut derived antigen(s) into the systemic circulation and development of a subsequent systemic IgG response. Relatively little IgG is normally synthesised within the large intestine,,$^{22}$ as we have shown above. In UC, however, the amounts of preformed tissue IgG are increased, as shown immunohistologically, " and by ourselves by direct measurement. Our data thus confirm the previous suggestion that most mucosal IgG is extravascular, and not synthesised locally. ${ }^{+}$Only in active UC is there any evidence for substantially raised local IgG production, ${ }^{37}$ whereas the patients we studied were all in remission and showed only a modest increase.

IgG is the predominant immunoglobulin isotype associated with immune complex formation and deposition. It is therefore likely that IgG type antigen-antibody complexes against disease related antigens are formed in the colonic mucosa in UC. ${ }^{23}$ Immune complexes are known to contribute substantially to inflammatory responses, and the occurrence of immune complexes in $\mathrm{UC}^{2+26}$ may play a major 
role in the maintenance of the chronic inflammatory state. ${ }^{19} 27$ Our observations of a modest increase of IgM production agrees with the above hypothesis, as IgM antibodies are principally elicited to primary antigenic exposure, and hence should not be markedly increased during chronic immunostimulation. It is, however, worth remembering that J-chain linked IgM can also be secreted in secretory component bound form; although we have not yet measured secretory IgM production, a defect of Jchain production in $\mathrm{UC}^{\prime 1}$ would suggest impaired sIgM secretion in addition to impaired SIgA production, thereby exacerbating the problem of defective local secretory immunity.

This work was supported in part by a grant from the Yorkshire Regional Health Authority. SB was supported by the Egyptian Cultural Bureau. The expert technical assistance of Mrs S Shires and Miss D J Oakes is acknowledged. The authors are indebted to Dr C J Smart for help with the manuscript, and to Mr S James for assistance with figures.

\section{References}

1 Brandtzaeg $\mathrm{P}$, Valnes $\mathrm{K}$, Scott $\mathrm{H}$, Ragnum TO, Bjeker $\mathrm{K}$, Baklein $\mathrm{K}$. The human gastrointestinal secretory system in health and disease. Scand J Gastroenterol [suppl] 1985; 20: 17.

2 Brandtzaeg $\mathrm{P}$. The $\mathrm{B}$ cell system. In: Brostoff J, Challacombe SJ, eds. Food allergy and intolerance London: Baillière Tindall, 1987: 118-55.

3 McClelland DBL, Schearman DJC, Lai A Fat RFM, Van Furth R. In vitro synthesis of immunoglobulins, secretory component, complement and lysozyme by human gastrointestinal tissues. II Pathological tissues. Clin Exp Immunol 1976; 23: 20.

4 Danis VA, Harries AD, Heatley RV. In vitro immunoglobulin secretion by normal human gastrointestinal mucosal tissues, and alterations in patients with inflammatory bowel disease. Clin Exp Immunol 1984; 56: 159.

5 Bookman MA, Bull DM. Characteristics of isolated intestinal mucosal lymphoid cells in inflammatory bowel disease. Gastroenterology 1977; 77: 503.

6 MacDermott RP, Nash GS, Bertovich MJ, Seiden MV, Bragdon MJ, Beale MG. Alterations of IgM, IgG and IgA synthesis and secretion by peripheral blood and intestinal mononuclear cells from patients with ulcerative colitis and Crohn's disease. Gastroenterology 1981; 81: 844 .

7 MacDermott RP, Beale MG, Alley CD, Nash GS, Bertovich MJ, Bragdon MJ. Synthesis and secretion of $\operatorname{IgA}$, IgM and IgG by peripheral blood mononuclear cells in human disease states, by isolated human intestinal mononuclear cells and by human bone marrow mononuclear cells from ribs. Ann NY Acad Sci 1983; 409: 498.
8 MacDermott RP, Nash GS, Bertovich MJ, et al. Altered patterns of secretion of monomeric $\operatorname{IgA}$ and $\operatorname{IgA}$ subclass 1 by intestinal mononuclear cells in inflammatory bowel disease. Gastroenterology 1986; 91: 379.

9 Rognum TO, Elgjo K, Fausa O, Brandtzaeg P. Immunohistochemical evaluation of carcinoembryonic antigen, secretory component and epithelial IgA in ulcerative colitis with dysplasia. Gut 1982; 23: 123 .

10 Uchima $\mathrm{H}$, Eishi $\mathrm{Y}$, Takemusa $\mathrm{T}$, Hirohawa $\mathrm{K}$. Immunohistochemical studies of ulcerative colitis. Acta Pathol Jpn 1983; 33: 1183.

11 Brandtzaeg P, Korsrud FR. Significance of different J chain profiles in human tissues: generation of $\operatorname{IgA}$ and IgM with binding sites for secretory component is related to the $J$ chain expressing capacity of the total local immunocyte population, including $\operatorname{IgG}$ and $\mathrm{IgD}$ producing cells, and depends on the clinical state of the tissue. Clin Exp Immunol 1977; 58: 709.

12 Soltoft J, Binder V, Gudmand-Hoyer E. Intestinal immunoglobulins in ulcerative colitis. Scand J Gastroenterol 1973; 8: 293.

13 Eastwood GL, Trier JS. Organ culture of human rectal mucosa. Gastroenterology 1973; 64: 375.

14 Howdle PD, Corazza GR, Bullen AW, Losowsky MS. Gluten sensitivity of small intestinal mucosa in vitro: quantitative assessment of histologic change. Gastroenterology 1981; 80: 442.

15 Wood GM, Howdle PD, Trejdosiewicz LK, Losowsky MS. Jejunal plasma cells and in vitro immunoglobulin production in adult coeliac disease. Clin Exp Immunol 1987; 69: 123 .

16 Wood GM, Trejdosiewicz LK, Losowsky MS. ELISA for measurement of secretory $\operatorname{IgA}$ distinct from monomeric IgA. J Immunol Methods 1987; 97: 269.

17 Brandtzaeg P, Baklein K, Fausa O, Hoel PS. Immunohistochemical characterisation of local immunoglobulin formation in ulcerative colitis. Gastroenterology 1974; 66: 1123 .

18 Skinner JM, Whitehead RC. The plasma cells in inflammatory disease of the colon: a quantitative study. J Clin Pathol 1974; 27: 643.

19 Baklien K, Brandtzaeg P. Comparative mapping of the local distribution of immunoglobulin-containing cells in ulcerative colitis and Crohn's disease of the colon. Clin Exp Immunol 1975; 22: 197.

20 Rosekrans PCM, Meijer CJLM Van Der Wal AM, Cornelisse CJ, Lindeman J. Immunoglobulin containing cells in inflammatory bowel disease of the colon: a morphometric and immunohistochemical study. Gut 1980;21: 941 .

21 Kett K, Brandtzaeg P. Local IgA subclass alterations in ulcerative colitis and Crohn's disease of the colon. Gut 1987; 28: 1013.

22 Walker WA, Isselbacher $\mathrm{KJ}$. Intestinal antibodies. $N$ Engl J Med 1976; 297: 767.

23 Nagai T, Das KM. Detection of colonic antigen(s) in tissues from ulcerative colitis using purified colitis colon tissue-bound IgG (CCA-IgG). Gastroenterology 1981; 81: 463 .

24 Koffler D, Minkowitz S, Rothman W, Garlick J. Immunohistochemical studies in ulcerative colitis and regional ileitis. Am J Pathol 1962; 41: 733. 
25 Ballard J, Shiner M. Evidence of cytotoxicity in ulcerative colitis from immunofluorescent staining of the rectal mucosa. Lancet 1974; i: 1014.

26 Otto HF, Gebbers JO. Immuno-histochemical observa- tions of the local immune response in ulcerative colitis. Inn Med 1978; 2: 69.

27 Mee AS, McLaughlin JE, Hodgson HJF, Jewell DP. Chronic immune colitis in rabbits. Gut 1979; 20: 1 . 